\title{
Front Matter: Volume 7996
}

, "Front Matter: Volume 7996," Proc. SPIE 7996, Fundamentals of LaserAssisted Micro- and Nanotechnologies 2010, 799601 (28 February 2011); doi: 10.1117/12.890734

SDIE Event: Fundamentals of Laser Assisted Micro- and Nanotechnologies 2010, 2010, St. Petersburg, Russian Federation 


\title{
PROCEEDINGS OF SPIE
}

\section{Fundamentals of Laser-Assisted Micro- and Nanotechnologies 2010}

\author{
Vadim P. Veiko \\ Tigran A. Vartanyan \\ Editors
}

\section{5-8 July 2010}

St. Petersburg, Russian Federation

Organized by

St. Petersburg State University of Information Technologies, Mechanics and Optics (Russian Federation)

General Physics Institute of the Russian Academy of Sciences (Russian Federation)

Sponsored by

Russian Federation Ministry of Education and Science (Russian Federation)

St. Petersburg State University of Information Technologies, Mechanics and Optics

(Russian Federation)

Russian Foundation for Basic Research (Russian Federation)

EOARD-European Office of Aerospace Research \& Development (United States)

A.M. Prokhorov General Physics Institute (Russian Federation)

Laser Track Ltd. (Russian Federation)

Lasers \& Apparatus TM (Russian Federation)

CE Lasertech Ltd. (Russian Federation)

Cooperating Organization

Laser Association, CE Lasertech Ltd. (Russian Federation)

Published by

SPIE 
The papers included in this volume were part of the technical conference cited on the cover and title page. Papers were selected and subject to review by the editors and conference program committee. Some conference presentations may not be available for publication. The papers published in these proceedings reflect the work and thoughts of the authors and are published herein as submitted. The publisher is not responsible for the validity of the information or for any outcomes resulting from reliance thereon.

Please use the following format to cite material from this book:

Author(s), "Title of Paper," in Fundamentals of Laser-Assisted Micro- and Nanotechnologies 2010, edited by Vadim P. Veiko, Tigran A. Vartanyan, Proceedings of SPIE Vol. 7996 (SPIE, Bellingham, WA, 2011) Article CID Number.

ISSN 0277-786X

ISBN 9780819485694

Published by

SPIE

P.O. Box 10, Bellingham, Washington $98227-0010$ USA

Telephone +1 3606763290 (Pacific Time) · Fax +1 3606471445

SPIE.org

Copyright (@ 2011, Society of Photo-Optical Instrumentation Engineers

Copying of material in this book for internal or personal use, or for the internal or personal use of specific clients, beyond the fair use provisions granted by the U.S. Copyright Law is authorized by SPIE subject to payment of copying fees. The Transactional Reporting Service base fee for this volume is $\$ 18.00$ per article (or portion thereof), which should be paid directly to the Copyright Clearance Center (CCC), 222 Rosewood Drive, Danvers, MA 01923. Payment may also be made electronically through CCC Online at copyright.com. Other copying for republication, resale, advertising or promotion, or any form of systematic or multiple reproduction of any material in this book is prohibited except with permission in writing from the publisher. The CCC fee code is 0277-786X/11/ \$18.00.

Printed in the United States of America.

Publication of record for individual papers is online in the SPIE Digital Library.

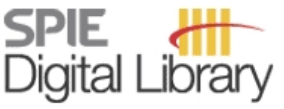

SPIEDigitalLibrary.org

Paper Numbering: Proceedings of SPIE follow an e-First publication model, with papers published first online and then in print and on CD-ROM. Papers are published as they are submitted and meet publication criteria. A unique, consistent, permanent citation identifier (CID) number is assigned to each article at the time of the first publication. Utilization of CIDs allows articles to be fully citable as soon they are published online, and connects the same identifier to all online, print, and electronic versions of the publication. SPIE uses a six-digit CID article numbering system in which:

- The first four digits correspond to the SPIE volume number.

- The last two digits indicate publication order within the volume using a Base 36 numbering system employing both numerals and letters. These two-number sets start with 00, 01, 02, 03, 04 , 05, 06, 07, 08, 09, OA, OB ... 0Z, followed by 10-1Z, 20-2Z, etc.

The CID number appears on each page of the manuscript. The complete citation is used on the first page, and an abbreviated version on subsequent pages. Numbers in the index correspond to the last two digits of the six-digit CID number. 


\section{Contents}

ix Conference Committee

xi Introduction

SESSION 1 LASER MATERIAL AND THIN FILMS PROCESSING

799602 Actual principles of the simulation of state-of-the-art technologies of laser processing of materials [7996-01]

O. B. Kovalev, Khristianovich Institute of Theoretical and Applied Mechanics

(Russian Federation)

799603 Analysis of internal crack propagation in silicon due to permeable pulse laser irradiation: study on processing mechanism of stealth dicing [7996-02]

E. Ohmura, Y. Kawahito, Osaka Univ. (Japan); K. Fukumitsu, J. Okuma, H. Morita, Hamamatsu Photonics K.K. (Japan)

799604 Research on the contrast of laser marks on precise surfaces of metal [7996-03] O. S. Yulmetova, St. Petersburg State Univ. of Information Technologies, Mechanics and Optics (Russian Federation); R. R. Yulmetova, Technical Univ. of Denmark (Denmark); V. N. Matyzhonok, St. Petersburg State Univ. of Information Technologies, Mechanics and Optics (Russian Federation)

799605 Laser induced multicolor image formation on metal surfaces [7996-04] S. G. Gorny, Laser Ctr. Ltd. (Russian Federation); G. V. Odintsova, A. V. Otkeeva, V. P. Veiko, St. Petersburg State Univ. of Information Technologies, Mechanics and Optics (Russian Federation)

799606 Reception of thin films from a liquid phase by means of laser radiation [7996-05] A. A. Antipov, S. V. Kutrovskaya, A. O. Kucherik, D. S. Nogtev, Vladimir State Univ. (Russian Federation)

799607 Mechanisms of thin Cr films modification under multipulse femtosecond laser action [7996-06]

V. P. Veiko, M. V. Yarchuk, A. I. Ivanov, St. Petersburg State Univ. of Information Technologies, Mechanics and Optics (Russian Federation)

799608 Laser-induced local transfer of glass-ceramic materials [7996-07]

V. U. Kasatkin, E. A. Shakhno, St. Petersburg State Univ. of Information Technologies, Mechanics and Optics (Russian Federation)

799609 Pulsed laser-induced forming of thin sheet metal [7996-08]

A. A. Petrov, A. D. Kochetov, St. Petersburg State Univ. of Information Technologies, Mechanics and Optics (Russian Federation) 
7996 OA Temperature monitoring in selective laser sintering/melting [7996-09]

Y. Chivel, Institute of Applied Physical Problems (Belarus); I. Smurov, Ecole Nationale d'Ingénieurs de Saint-Etienne (France)

7996 OB Conical and volumetric laser beams in laser technologies [7996-10]

Y. Chivel, Institute of Applied Physical Problems (Belarus); N. Khilo, B.I. Stepanov Institute of Physics (Belarus)

7996 OC Adaptive control system for laser micromachining devices [7996-11]

V.P. Bessmeltsev, E. D. Bulushev, N. V. Goloshevsky, Institute of Automation and Electrometry (Russian Federation)

7996 OD Diode pumped Er:YLF laser with funable lasing spectrum [7996-12]

M. V. Inochkin, L. V. Khloponin, V. Y. Khramov, D. Y. Sachkov, V. V. Nazarov, St. Petersburg

State Univ. of Information Technologies, Mechanics and Optics (Russian Federation)

\section{SESSION 3 NANOTECHNOLOGY}

7996 OE Synthesis and optical property of nanostructured ZnO crystals by nanoparticle-assisted pulsed laser deposition [7996-13]

D. Nakamura, T. Okada, Kyushu Univ. (Japan); K. Sakai, Univ. of Miyazaki (Japan)

7996 OF Plasmon-enhanced optics and magneto-optics via the near field of a nanowire [7996-14] V. A. Kosobukin, Ioffe Physico-Technical Institute (Russian Federation)

7996 OG Nanofabrication of GaN surfaces by ultrashort laser pulses [7996-15] S. Nakashima, K. Sugioka, RIKEN (Japan); T. Ito, RIKEN (Japan) and Tokyo Denki Univ. (Japan); H. Takai, Tokyo Denki Univ. (Japan); K. Midorikawa, RIKEN (Japan)

$7996 \mathrm{OH} \quad$ Shaping of surface nanostructures via non-thermal light-induced processes [7996-16] T. A. Vartanyan, V. V. Khromov, N. B. Leonov, S. G. Przhibelskii, St. Petersburg State Univ. of Information Technologies, Mechanics and Optics (Russian Federation)

7996 Ol Alteration in structure of nanometer films of polymethine dyes [7996-17] E. N. Kaliteevskaya, V. P. Krutyakova, T. K. Razumova, A. A. Starovoytov, Y. M. Voronin, St. Petersburg State Univ. of Information Technologies, Mechanics and Optics (Russian Federation)

7996 0J Photo-ionization and modification of nanoparticles on transparent substrates by ultrashort laser pulses [7996-18]

V. Gruzdev, Univ. of Missouri-Columbia (United States); V. Komolov, St. Petersburg State Univ. of Information Technologies, Mechanics and Optics (Russian Federation); H. Li, Q. Yu, Univ. of Missouri-Columbia (United States); S. Przhibel'skii, D. Smirnov, St. Petersburg State Univ. of Information Technologies, Mechanics and Optics (Russian Federation) 
7996 OK Enhanced photoconductivity in silver nanoparticle ensembles owing to the excitations of localized surface plasmon polariton resonances (LSPPRs) [7996-19]

E. V. Vaschenko, T. A. Vartanyan, V. V. Khromov, N. B. Leonov, S. G. Przhibelskii, St. Petersburg State Univ. of Information Technologies, Mechanics and Optics (Russian Federation);

F. Hubenthal, Univ. Kassel (Germany)

7996 OL Synthesis of nanometric iron and chromium oxide films by reactive pulsed laser deposition for photo-thermo sensors [7996-20]

S. A. Mulenko, Institute for Metal Physics (Ukraine)

$79960 \mathrm{M}$ Stochastic fields in a nanoscale vicinity of the ionic crystal surfaces at finite temperatures [7996-21]

S. G. Przhibel'skii, St. Petersburg State Univ. of Information Technologies, Mechanics and Optics (Russian Federation)

7996 ON Light scattering by axisymmetric particles: the separation of variables method with spheroidal basis [7996-22]

V. G. Farafonov, St. Petersburg State Univ. of Aerospace Instrumentation

(Russian Federation); V. B. Il'in, Pulkovo Astronomical Observatory (Russian Federation), St. Petersburg State Univ. (Russian Federation), and St. Petersburg State Univ. of Aerospace Instrumentation (Russian Federation); A. A. Vinokurov, St. Petersburg State Univ. of Aerospace Instrumentation (Russian Federation) and Pulkovo Astronomical Observatory (Russian Federation)

799600 Surface plasmon polariton dispersion of the vacuum-plasma of emitted electrons boundary and the periods of femtosecond laser-induced microstructures on metals [7996-23]

V.S. Makin, Research Institute for Complex Testing of Optoelectronic Devices and Systems (Russian Federation); R. S. Makin, Ulyanovsk State Univ. (Russian Federation); I. A. Silantjeva, Research Institute for Complex Testing of Optoelectronic Devices and Systems (Russian Federation)

\section{SESSION 4 FEMTOTECHNOLOGY}

7996 OP Femtosecond dynamics of optical properties of semiconductor [7996-24]

R. V. Dyukin, G. A. Martsinovskiy, I. Yu. Khvan, G. D. Shandybina, E. B. Yakovlev, I. D. Nikiforov, St. Petersburg State Univ. of Information Technologies, Mechanics and Optics (Russian Federation)

$79960 Q \quad$ Localized phase separation inside glass by femtosecond laser-induced elemental migration [7996-25]

M. Shimizu, K. Miura, M. Sakakura, M. Nishi, Y. Shimotsuma, S. Kanehira, K. Hirao, Kyoto Univ. (Japan)

7996 OR Modification of photosensitive glass-ceramic Foturan by ultrashort laser pulses [7996-26] E. Ageev, St. Petersburg State Univ. of Information Technologies, Mechanics and Optics (Russian Federation); K. Kieu, College of Optical Sciences, The Univ. of Arizona (United States); V. P. Veiko, St. Petersburg State Univ. of Information Technologies, Mechanics and Optics (Russian Federation) 
7996 OS Effect of laser irradiation on the structures properties such as $\mathrm{SiO}_{2} / \mathrm{Si}$ [7996-27]

V. P. Veiko, A. M. Skvortsov, St. Petersburg State Univ. of Information Technologies, Mechanics and Optics (Russian Federation); V. I. Sokolov, loffe Physico-Technical Institute (Russian Federation); Q. T. Pham, R. A. Khalecki, E. I. Efimov, St. Petersburg State Univ. of Information Technologies, Mechanics and Optics (Russian Federation)

7996 OT Ablation by short optical and $x$-ray laser pulses [7996-28]

N. A. Inogamov, S. I. Anisimov, Landau Institute for Theoretical Physics (Russian Federation); V. V. Zhakhovsky, Joint Institute for High Temperatures (Russian Federation) and Univ. of South Florida (United States); A. Ya. Faenov, Joint Institute for High Temperatures (Russian Federation) and Japan Atomic Energy Agency (Japan); Yu. V. Petrov, V. A. Khokhlov, Landau Institute for Theoretical Physics (Russian Federation); V. E. Fortov, M. B. Agranat, S. I. Ashitkov, P. S. Komarov, I. Yu. Skobelev, Joint Institute for High Temperatures (Russian Federation); Y. Kato, The Graduate School for the Creation of New Photonics Industries (Japan); T. A. Pikuz, Joint Institute for High Temperatures (Russian Federation) and Japan Atomic Energy Agency (Japan); V. V. Shepelev, Institute for Computer Aided Design (Russian Federation); Y. Fukuda, M. Tanaka, M. Kishimoto, M. Ishino, M. Nishikino, M. Kando, T. Kawachi, Japan Atomic Energy Agency (Japan); M. Nagasono, RIKEN (Japan); H. Ohashi, M. Yabashi, RIKEN (Japan) and Japan Synchrotron Radiation Research Institute (Japan); K. Tono, RIKEN (Japan); Y. Senba, Japan Synchrotron Radiation Research Institute (Japan); T. Togashi, RIKEN (Japan) and Japan Synchrotron Radiation Research Institute (Japan); T. Ishikawa, RIKEN (Japan)

7996 OU Effect of electron emission on solids heating by femtosecond laser pulse [7996-29] V. V. Svirina, O. N. Sergaeva, E. B. Yakovlev, St. Petersburg State Univ. of Information Technologies, Mechanics and Optics (Russian Federation)

\section{SESSION 5 LASER PLASMA AND LASER-PLASMA DEPOSITION}

7996 OV On the self-similar solution of laser ablated plasma expansion [7996-30]

R. Fermous, Univ. des Sciences et de la Technologie Houari Boumediene (Algeria);

D. Doumaz, Ctr. de Développement des Technologies Avancées (Algeria); M. Djebli, Univ. des Sciences et de la Technologie Houari Boumediene (Algeria)

7996 OW Time-of-flight characterization of ZnO laser-generated plasma [7996-31]

A. M. Mezzasalma, G. Mondio, Univ. degli Studi di Messina (Italy) and INFN (Italy); L. Torrisi, F. Caridi, INFN (Italy) and Univ. degli Studi di Messina (Italy)

7996 0X Laser induced metal ablation at high ambient gas pressure [7996-32]

Y. Chivel, V. Nasonov, Institute of Applied Physical Problems (Belarus)

7996 OY Laser produced plasma expansion across transverse magnetic field [7996-33]

D. Bennaceur-Doumaz, Ctr. de Développement des Technologies Avancées (Algeria);

M. Djebli, Univ. des Sciences et de la Technologie Houari Boumediene (Algeria) and Ctr. de Développement des Technologies Avancées (Algeria)

$79960 Z$ Pulsed laser deposition $\mathrm{CN}_{\mathrm{x}}$ films and carbon plume dynamic study [7996-34]

S. Abdelli-Messaci, S. Lafane, T. Kerdja, Ctr. de Développement des Technologies Avancées

(Algeria); M. Siad, A. Guittoum, Ctr. de Recherche Nucléaire d'Alger (Algeria) 
799610 Study and simulation of the growth of MoSe $e_{x}$-based thin film coatings formed by pulsed laser deposition [7996-35]

V. Yu. Fominski, National Research Nuclear Univ. MEPhl (Russian Federation);

A. G. Gnedovets, A.A. Baikov Institute of Metallurgy and Materials Science

(Russian Federation); R. I. Romanov, G. G. Kalustyan, National Research Nuclear Univ. MEPhl (Russian Federation)

\section{SESSION $6 \quad$ PHOTONICS}

$799611 \quad$ New holographic method for formation of 2D gratings in photorefractive materials by Bessel standing wave [7996-36]

A. Badalyan, R. Hovsepyan, V. Mekhitaryan, P. Mantashyan, R. Drampyan, Institute for Physical Research (Armenia)

799612 Increasing of the EUV resist's sensitivity [7996-37]

M. S. Kitai, Institute on Laser Information Technologies (Russian Federation); A. M. Soroka, JSC Innovation Manufacturing Complex (Russian Federation); I. G. Rudoi, JSC, MagAlTech (Russian Federation)

799613 Resonant diffusive reflection of light from rough interfaces of Bragg structures (photonic crystals) [7996-38]

Y. N. Lazareva, Baltic State Technical Univ. (Russian Federation); V. A. Kosobukin,

A. V. Sel'kin, Ioffe Physico-Technical Institute (Russian Federation)

\section{SESSION 7 LASER CLEANING}

799614 Application of laser in conservation and restoration of historical building [7996-39] V. Detalle, S. Duchêne, V. Verges Belmin, Lab. de Recherche des Monuments Historiques (France); J. M. Vallet, Ctr. Interregional de Conservation et Restauration du Patrimoine (France); J. L. Bodnar, Univ. de Reims Champagne-Ardenne (France)

799615 Cleaning laser spark spectroscopy for online cleaning quality control method development [7996-40]

T. Y. Mutin, V. N. Smirnov, V. P. Veiko, S. A. Volkov, St. Petersburg State Univ. of Information Technologies, Mechanics and Optics (Russian Federation)

799616 Laser assisted graffiti paints removing [7996-41]

B. Y. Novikov, Y. V. Chikalev, E. A. Shakhno, St. Petersburg State Univ. of Information Technologies, Mechanics and Optics (Russian Federation)

799617 Laser rail cleaning for friction coefficient increase [7996-42]

V. P. Veiko, A. A. Petrov, St. Petersburg State Univ. of Information Technologies, Mechanics and Optics (Russian Federation); A. S. Maznev, A. M. Evstafev, A. A. Kalinina, St. Petersburg State Univ. of Transport (Russian Federation)

Author Index 
Downloaded From: https://www.spiedigitallibrary.org/conference-proceedings-of-spie on 26 Apr 2023

Terms of Use: https://www.spiedigitallibrary.org/terms-of-use 


\section{Conference Committee}

\section{Conference Committee}

Honorary Chairs

Vladimir N. Vasiliev, St. Petersburg State University of Information

Technologies, Mechanics and Optics (Russian Federation)

Ivan A. Shcherbakov, General Physics Institute of Russian Academy of

Sciences (Russian Federation)

Conference Chairs

Vadim P. Veiko, Saint-Petersburg State University of Information Technologies, Mechanics and Optics (Russian Federation)

Vitaly I. Konov, General Physics Institute of Russian Academy of Sciences (Russian Federation)

Program Committee Cochairs

B. Chichkov, Laser Zentrum (Germany)

S. Garnov, General Physics Institute of Russian Academy of Sciences (Russian Federation)

M.J. Soileau, University of Central Florida (United States)

K. Sugioka, RIKEN (Japan)

V. Veiko, St. Petersburg State University of Information Technologies, Mechanics and Optics (Russian Federation)

Scientific Secretary

V. Krutyakova, St. Petersburg State University of Information Technologies, Mechanics and Optics (Russian Federation)

International Program Committee

S. Anisimov (Russian Federation)

C. Arnold (United States)

S. Ashmontas (Lithuania)

F. Bachmann (Germany)

A. Caricato (Italy)

O. Efimov (United States)

M. Farsari (Greece)

S. Gaponov (Russian Federation)

V. Gapontsev (Russian Federation)
A. Medvids (Latvia)

M. Meunier (Canada)

I. Mihailescu (Romania)

V. Ochkin (Russian Federation)

A. Ostendorf (Germany)

V. Panchenko (Russian Federation)

A. Pique (United States)

A. Poleshchuk (Russian Federation)

R. Poprawe (Germany) 
S. Garanin (Russian Federation)

V. Gordienko (Russian Federation)

V. Gruzdev (United States)

I. Gurov (Russian Federation)

H. Helvajian (United States)

P. Hermann (Canada)

F. Hubenthal (Germany)

P. Kashkarov (Russian Federation)

W. Kautek (Austria)

O. Khasanov (Belarus)

V. Komolov (Russian Federation)

S. Kozlov (Russian Federation)

Lu Yongfeng, (United States)

B. Luk'yanchuk (Singapore)
B. Rethfeld (Germany)

A. Semerok (France)

A. Sergeev (Russian Federation) I. Shiganov (Russian Federation)

A. Shkurinov (Russian Federation) I. Smurov (France)

C. Stolz (United States)

T. Szörenyi (Hungary)

F. Träger (Germany)

Y. Tsuboi (Japan)

G. Turichin (Russian Federation)

T. Vartanyan (Russian Federation)

E. Wintner (Austria)

E. Yakovlev (Russian Federation)

Organizing Committee Cochairs
A. Allas
E. Brui
V. Komolov
E. Yakovlev 


\section{Introduction}

This volume presents selected papers of the International Conference on "Fundamentals of Laser-Assisted Micro- and Nanotechnologies" (FLAMN-10).

This conference continues in a new format from well-known traditional symposia ILATA (Intensive Laser Actions and Technological Applications), consisting of LAMN (Laser-Assisted Microtechnologies) and LMI (Laser-Matter Interaction) conferences, originally organized in former Leningrad, USSR since the middle of the 1960's. Laser-assisted micro- and nanotechnology is one of the first and rapidly growing areas of research, development, and production.

The Conference was devoted to the wide spectrum of laser micro- and nanoprocessing from physical fundamentals of different processes and their experimental demonstration to industrial set-ups and their realization. Topics covered by FLAMN-10 include theoretical and experimental aspects of lasermatter interaction applied to laser micro- and nanotechnology.

Sessions of FLAMN-10 were attended by over 300 participants including 180 speakers, approximately 75 of them from abroad (Algeria, Australia, Belarus, Canada, China, Czech Republic, France, Germany, Hungary, Greece, Italy, Japan, Korea, Serbia, Singapore, Taiwan, United Kingdom, Ukraine, and the United States). About 185 papers were presented (75 orals, 110 posters); this volume contains 40 selected papers.

For the convenience of readers, all papers in these proceedings are arranged into seven sections:

Section 1: Laser material and thin films processing

Section 2: Control of laser material processing

Section 3: Nanotechnology

Section 4: Femtotechnology

Section 5: Laser plasma, laser-plasma deposition

Section 6: Photonics

Section 7: Laser cleaning

The Program Committee expresses its gratitude to all the institutions and persons who contributed to organizing, supporting, and holding the conference. 
Personal thanks to the FLAMN-10 cooperating and sponsoring organizations.



ITMO

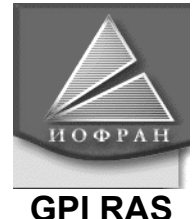

GPI RAS



State Museum

"Tzarskoje Selo"

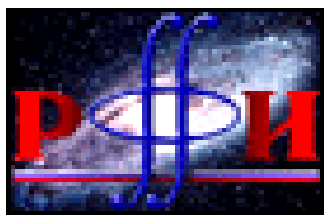

RFBR

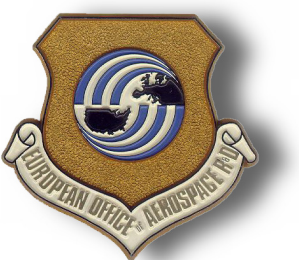

EOARD

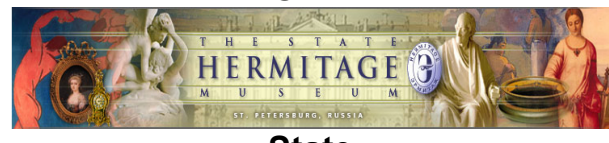

State

Hermitage Museum

Vadim P. Veiko

Tigran A. Vartanyan 